\title{
DICK, Kirby and ZIERING, Amy. 2016. The Hunting Ground. The inside story of sexual assault on American college campuses. México: Hot Books, 188 pp.
}

doi: http://dx.doi.org/10.18543/djhr-3-2018pp209-214

The Hunting Ground started to initially be a documentary released in 2015 daring to present on the big screen, the sexual violence on the United States college campuses. The filmmakers Kirby Dick and Amy Ziering were the Academy Award winners of the film "The Invisible war", which tackles the sexual violence happening in the army context. While they were running along the United States college campuses screening "The Invisible War" and discussing about the silence perpetuated into the army, students were raising their hands from the public, claiming the gender violence also exits within the academy. According to its producers, The Hunting Ground is the consequence of directly interviewing around 70 people on camera and more than 200 in off-camera dialogues. One year after its first release, the documentary's impact was uncountable. The visionary of this documentary at each university, contributed to trigger discussion about the issue of sexual harassment, started activism among its community and initiating change.

While the producers were moving from one campus to another talking about the issue of sexual violence in university, they were always sharing similar situations, meaning listening stories and feeling the students need of being heard, understood and supported. In this sense, the huge amount of screenings around universities have allowed victims to break their silence and speak out about their cases, while joining their power to organize themselves; symbolizing in most cases the strongest fight ever against sexual harassment at their universities. As Annie Clark, athlete and testimony of The Hunting Ground, express: "I graduated third from High School. I could go anywhere, and UNC [University of North Caroline] was the best school. I really had a good time there. I learned a lot, I loved my professors. The first few weeks, I met some of my best friends, and we are still really, really close, but two of us were sexually assaulted before classes even started". Thus, the documentary has not only contributed to show the silence about sexual assault on college campuses and how universities tend to develop strategies to hide it, but also to focus on the ways in which students, victims and activists organize themselves, taking the issue seriously and making their voices heard. Clearly and carefully, the film 
emphasizes the student mobilization produced by the End Rape on Campus (EROC) student network of survivors which grows and extends along the documentary, until the point of achieving great social and political impact bringing the issue to the highest spectrum of social and political interest.

In the same line, the movement generated around the documentary release has contributed to potentially manifest the huge emergency on approaching campus sexual assault in other countries around the world. Reactions to this film have been mostly positive. Besides being a useful tool in helping to bring change, they pushed university administrators to act against cases of violence. While it is also true that some universities, companies and individuals have spread criticism against Dick and Ziering work, they have also been pressed for acting to change dynamics. Positive examples in this sense, arise for instance, from some university's chancellors who publically apologized for the way sexual harassment had been approached. This is the case of the University of Alaska for instance, who wrote a public letter apologizing for the "lack of action" regarding cases of sexual assault.

In 2016, The Hunting Ground book came up shedding light on real narratives on sexual assault and their links with fraternities, sports, family, all around the problem of reputation, donations, but especially on solidarity with survivors; considering how university prestige may worry administrators making them change their discourse and action around the issue, being pressed by the huge public significance the documentary achieved. Thus, the book is dedicated to student movements and the impact they started to embody once The Hunting Ground has been released.

The Hunting Ground describes the stories of three victims of sexual violence in college, who soon become survivors and then activists: Annie, Andrea and Sofie. Shortly after e-meeting each other, they decided to create a network across the country ready to help other survivors to fill complaints and get empowered, while assisting them and their communities. This is how End Rape on Campus was born in 2013. All of them experienced sexual violence on campus and reported their cases to the existing university mechanisms. However, they all agreed on the fact that their college did not take seriously their complaints neither their own situations. In fact, they believe their universities were trying to undermine the devastating experiences they had suffered. As they explain, EROC emerged from their lack of knowledge on felling a complaint, their rights and duties and the lack of support from their schools. "I knew I had to do something, 
about that, and it was when another friend come to me and said: "I was assaulted at a fraternity, how do I report?". I told her that I was assaulted too, and we sit down and slop out Google and started to know how to report" (The Hunting Ground' founder). Even if some of these universities embrace a long history of students' activism; the activism against sexual harassment in academia is getting to the public light by hands of courageous young women who have bravely decide to take a stand in favor of all survivors and against the institutions covering-up cases; as a way of protecting academia and leaving it free of harassment.

From the introduction, Constance Matthiessen -as editor of The Hunting Ground book - introduces some key issues analyzed along the book: the sexual assault as campus epidemic; the fraternities and athletics as places where the culture of rape and cover-up is being perpetuated and silenced; the political repercussions as signals for change, taking as example the Obama administration and their policies against harassment in universities.

In the first chapter of this book, four stories of sexual assault illustrate the voices of survivors. One man, two women and one person identified as queer tell their stories of surviving sexual harassment at their dream college. Their personal background and the consequences that harassment evokes on them provide to the reader a strong understanding on how hard it gets to face the everyday life as survivor; at the same time, these narratives raise awareness and engage people into the struggle against sexual violence. "I did not tell anybody for a long time. I went to classes; I did everything kind of normally, but something in the back of my mind really started to affect me" (Testimony of The Hunting Ground).

The second chapter describes the sexual assault in a football town. According to this story, the protection that a football player may get is enormous, just because his fans want to see him playing. This is the case expressed by Erika, one of the The Hunting Ground protagonists. A very important player raped her. Once Erika recognized him on the TV, she empowered herself and asked for help on Twitter: "someone help me?" The whole investigation regarding the case and the DNA test, proven that the facts occurred. Nevertheless, Erika's story exemplifies how difficult it is to be believed as a survivor, when handing a complaint, but power and reputation are involved. Even the aim of the campus police body, according to the authors, is designed at protecting the institution, and in this case even harder, being the aggressor a star athlete. Still, the saddest, it involves questioning survivors and leaving them alone in the process of complaining and 
healing. For this reason, the second part of this chapter shows the attempts of the institutions to silence the truth. However, initiatives like the ones in this documentary and this book are bringing hope by showing a clear and firm positioning from some people side, which show the pressure it exerts on some institutions that can no longer look the other way.

Chapter three focuses on a concrete narrative, emphasizing some very important details that might be common for other survivors. Usually survivors tend to not daring to share their stories in public, and so, from the media perspective it becomes hard to get someone available to speak and tell his or her story of sexual violence. This chapter also approach the institutional backlashes survivors may suffer, as a limitation for them to speak up. The case of the student described on here, points out the debate about consent for any sexual engagement. Mostly, peer harassment situations use to be distinguished, most frequently, by the incapable and unconscious consent. As the book shown, when the harasser is other student, it gets harder for any institution to act against the student due to the aim of protecting their reputation. Taking the positive side of this reality, social mobilization against harassment in universities is achieving a shift on this sense, meaning protecting reputation through changing universities position, having them in favor of survivors. Indeed, student mobilization has contributed to change this perspective on campuses. Universities taking a clear stand in handling cases of sexual violence improve reputation. Indeed, other universities, which still consider the recognition and action against sexual harassment as losing reputation, are starting to find difficulties when looking the other way; and so, feeling the pressure for change. In this sense, universities become safer places when they positively deal with sexual harassment. For instance, when the number of complaints increases, means a positive consequence, so students trust their institutions to complain, they may feel comfortable and supported.

Chapter four points out fraternities as places in which sexual assault may happen. The so called rape culture is promoted there, usually involving drinking and an atmosphere pressing students to get involved in the sexual assault history. The book pretends to focus the American fraternity industry in which colleges, from the most elite to regional, engage. The criticism of the book to this regard stays on the bad reputation frat houses have, the unconformable atmosphere for most women there and the need for informing students of the college life perpetuated at fraternities. 
In chapter five, the authors present a collection of stories written by anti-assault activists, journalists, university professors, writers, film experts, but all of them familiar with the issue of sexual violence. Their diversity, their different opinions on tackling similar issues, some of them being survivors themselves, make of this chapter a great collection of stories to continue the advances of policy advocacy and the potential of women within the academic pathway. The End Rape on Campus organization has developed a wide variety of actions, prevention programs, student advocates and support networks across the United States and beyond their borders; contributing to policy reforms at the local, state and federal levels. This chapter also underlines campus sexual assault is an urgent male issue. While it is important, authors say, to teach men not to rape; most important is the training for consent, what consenting means and what consent is not. However, both the book and the documentary pretend to attack harassment, not men. This is important in terms of linking sexual violence to aggressors. In this sense, the book pretends to make clear that many men students are worthy of admiration, indeed the majority of men do not harass, rather the contrary; according to some statistics, men are most likely to be victims of sexual harassment in university than to be aggressors.

Chapter six pretends to show the profile of the producers and filmmakers Amy Ziering and Kirby Dick whose commitment against sexual harassment make them engage on the struggle in a very deep way, much further away that just doing their job, but changing public awareness about campus sexual assault and encouraging victims to move forward and get successful. The platform they provide for raising awareness and empower victims, also shed light on numbers and statistics, presented in chapter seven. Different scholars and several administrations are working on the issue from a quantitative perspective. The Department of Justice, the Association of American Universities, the National Crime Victimization Survey, the National Academies of Science, constitute some examples of mechanisms for collecting data on women in institutions and sexually assaulted women to provide rates of sexual assault. Finally, the book ends with useful information to get involved into action against harassment.

Rather than only describing the reality, this book pretends to create action and to break the silence, the impunity and complicities that permit sexual violence to be perpetuated in college campuses. In academia, because of the silence and fear of backlashes, victims find later on that they have not been the only ones harassed, just because 
people do not talk about that. While it is true that statistics show a huge number of cases which are never going to be reported, we are also facing a worldwide revolution in terms of empowerment, victims support and so, silence breaking. All together, the impact of these mobilizations and the media coverage received is being striking and hopeful for future generations.

Ana Vidu

University of Deusto 


\section{Copyright}

Deusto Journal of Human Rights / Revista Deusto de Derechos Humanos is an Open Access journal; which means that it is free for full and immediate access, reading, search, download, distribution, and reuse in any medium only for non-commercial purposes and in accordance with any applicable copyright legislation, without prior permission from the copyright holder (University of Deusto) or the author; provided the original work and publication source are properly cited (Issue number, year, pages and DOI if applicable) and any changes to the original are clearly indicated. Any other use of its content in any medium or format, now known or developed in the future, requires prior written permission of the copyright holder.

\section{Derechos de autoría}

Deusto Journal of Human Rights / Revista Deusto de Derechos Humanos es una revista de Acceso Abierto; lo que significa que es de libre acceso en su integridad inmediatamente después de la publicación de cada número. Se permite su lectura, la búsqueda, descarga, distribución y reutilización en cualquier tipo de soporte sólo para fines no comerciales y según lo previsto por la ley; sin la previa autorización de la Editorial (Universidad de Deusto) o la persona autora, siempre que la obra original sea debidamente citada (número, año, páginas y DOI si procede) y cualquier cambio en el original esté claramente indicado. Cualquier otro uso de su contenido en cualquier medio o formato, ahora conocido o desarrollado en el futuro, requiere el permiso previo por escrito de la persona titular de los derechos de autoría. 